How to Cite

Mathur, S. (2019). Sustainability practices as competitive edge on five star hotels of delhi: a study on manager's

perception. International Journal of Business, Economics \& Management, 2(1), 31-37. https://doi.org/10.31295/ijbem.v2n1.64

\title{
Sustainability Practices as Competitive Edge on Five Star Hotels of Delhi: A Study on Manager's Perception
}

\author{
Shweta Mathur \\ Amity University NOIDA, Uttar Pradesh, India \\ Email: shwetasmathur@gmail.com
}

\begin{abstract}
The study aims to conduct an analysis describing the sustainable strategy available for hotels, evaluating its potential to create competitive advantage and exploring how its implementation influences other actors in the industry specifically and the whole area development generally. For the purpose of this study, Delhi has been chosen with a focus on the Five Star and Five-star Deluxe Hotels of the city. A survey was conducted with the employees working in 15 Five star and Five-star Deluxe Hotels in Delhi. According to the analysis, the sustainable efforts of the hotel include environmental, social and economic initiatives. The results of the survey highlighted the sustainability practices that are being adopted and the extent of their implementation by these hotels. It also showed the relationship between a hotel's sustainability practices and employees' satisfaction. Furthermore, the study has explored the ability of sustainable efforts to create a unique reputation for the hotel which may enable it to gain a competitive edge. The latter, in turn, attracts the business customers who consider the sustainable hotel as a valuable partner for their own reputation. All in all, as the sustainability practices enhance profitability, it is considered a source of completive advantage.
\end{abstract}

Keywords---competitive advantage, Delhi, five-star hotels, sustainability.

\section{Introduction}

Sustainability is increasingly recognized as a cornerstone of competitive advantage in today's business landscape. This trend is expected to grow. Sustainability is a word that has been much talked about in most sectors of the economy especially in the Hospitality sector. This paper will focus on the holistic sustainable concept, by concentrating especially on five-star hotels in Delhi that have to face the problems of limited space available and of being less often considered for performing green practices.

This is a reason why most city hotels that decide to follow a sustainable strategy usually have to start at the bottom of sustainable development that accounts for restructured long-term saving plans in energy and resource management. Specifically in a business environment, sustainability "generally refers to the ability of a company to do business in a fashion that minimizes pollution and reflects careful management of natural resources. (Esty, 2011)" The term 'Sustainability' relates to meeting the needs of the present without compromising the ability of future generations to meet their own needs (Brundtland, 1987). This early definition has been applied in business contexts as corporate social responsibility (CSR), the voluntary but near-mandate to contribute to social, environmental and cultural wellbeing along with company profitability (Kotler \& Lee, 2004; Visser, 2010; Werbach, 2009). In turn, CSR has been rendered more compliant by its translation into 'triple bottom line' (TBL) or 'people, planet and profit' rubrics (Elkington, 1998, 2008), designed to track social and environmental progress in addition to wealth creation. In other words, 'Sustainability' requires building harmony between environmental, social equity and economic demands - also referred to as the "three pillars" of sustainability. It ensures that we have and will continue to have the water, materials, and resources to protect human health and our environment (Pérez et al., 2018; Gamez et al., 2019).

ISSN 2632-9476

Received Jan 20, 2019 / Accepted Jun 18, 2019 / Published Jul 05, 2019 


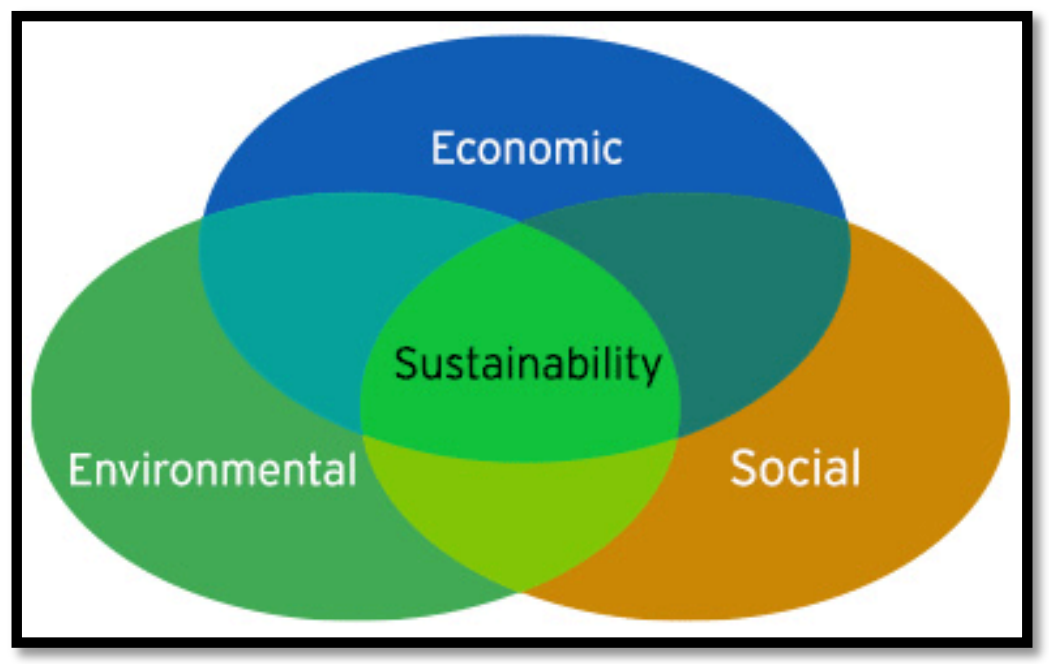

\section{Dimensions of Sustainable Strategy}

The last century, mankind has immensely damaged vast majority of its natural habitat which is still continuing. According to Munier (2005), “...humankind has very effectively managed to squander the earth's resources, clear-cutting a large amount of 12 existing forests, contaminating the atmosphere, polluting rivers, and even altering our climate."As a matter of fact, the economy utilizes natural resources to produce. Since our society is entirely dependent on those scarce resources, it must protect them in order to uphold the economy.

It is widely argued where the concept of sustainable development had its beginning, as concern about the society's impact on the environment was already an issue at the beginning of the 20th century. However, the birth of the sustainable development movement can be associated with the United Nations Conference on the Human Environment in Stockholm in1972, which was the first major UN conference that had a concern about environmental issues on a global scale as the main agenda (Dauvergne, 2005). After some dramatic events such as the Bhopal Gas tragedy in India in 1984 and the nuclear accident in Chernobyl in 1986, governments worldwide were induced to implement stricter regulations and laws on companies' behavior towards the environment (Blackburn, 2007).

It has long been known that social responsibility and attitude for sustainability are becoming factors of great importance for businesses across all industries (Porter \& Derry, 2012). This is the result of a general increase in awareness of these issues among the public, which subsequently affects the demand for businesses to comply to new standards of practice and accountability (Porter \& Derry, 2012). As a result, the initiator of sustainable efforts may become an initial impetus to the sustainable urban development in a city or area (Tryggestad, Georg \& Hernes, 2010). The type of business which can play such a role is hotels. In fact, as the hotel represents a building, the success of its sustainable practices and technologies may cause the spillover effect on its competitors. Historically, hotel owners saw sustainable efforts as expenses for economic performance (Mihalič, 2012). For this reason, attention to "green" technologies was weak before the 21st century (Mihalič, 2012). Today the sustainability is slowly becoming a dominant theme in the hotel industry (Spilanis \& Vayanni, 2004). In order to extract benefits from this situation, some hotels started the implementation of various "environment-friendly" technologies and their promotion in order to differentiate its offering and, consequently, outperform the competition (Green Building Elements, 2013).

\section{Literature Review}

The term 'Sustainability' has become a focal point for service organizations nowadays (Porter, 2012). The concept of Sustainability encompasses various definitions. According to the World Commission on Environment and Development (Brundtland, 1987), sustainable development ensures the meeting of the present generation needs without compromising the ability of future generations to satisfy their own needs. Sustainability simply implies that a given activity or action is capable of being continued indefinitely (Johnston, 2007). In this paper Sustainability is considered as the "Triple Bottom Line" - People, Profits and Planet, famously coined by (Elkington, 1994), arguing 
for the need for a balanced approach to development. "Triple bottom line" approach as integrating people, planet, and profits into all management actions or decisions was further asserted by (Wirtenberg, 2012).

According to (Prairie, 2012), the hotel industry is in the midst of a sustainability awakening. Due to the current state of the environment, businesses and industries have begun to incorporate sustainability practices to meet consumers' environmental issue concerns, current industry standards, and to create an environment of sustainable development for future generations. This section reviews research on sustainability practices in the hospitality industry (Basak et al., 2017; Gorda et al., 2018).

Hotels have incorporated environmental practices to reduce their impact on the environment probably owing to cost savings, media pressure, laws, or environmental consciousness and awareness (Revilla, 2001). According to (Jai Rathore, 2009), "Hotels have thoughtfully adopted various operational sustainability practices that help them save a great amount of money but have little to improve energy efficiencies and environment-friendly building designing at the project phase." Orie Berezan (2010), measured the impact of environment hotel practices on Guest satisfaction and the motivating factors for them to pay a higher premium for environment-friendly room in Hotels in Mexico.

Competitive Advantage in view of Grant (2010), represents the company's advantage over its rivals that helps to earn a persistently higher rate of profit. There is a research gap in the service sector to prove whether or not sustainable service businesses can benefit from sustainability, (Gupta, 2012). The industries in the service sector differ a lot and, hence, have different reliance on sustainability. According to Mark Vickers (2007-2017), sustainability-related best practices often represent competitive advantages for organizations, through a global ethic of "open source". The best practices are associated with their developers, who receive acceptance and applause that are often used in advertising campaigns to strengthen their brands. Contradictory to this, Sustainability approach is not practiced too widely because it costs too much and so dampens competitiveness.

\section{Objectives of the Study}

1. To find out the prevailing sustainability practices of Five Star Hotels in Delhi.

2. To study the influence of sustainability practices on the actions of Competing Hotels in Delhi.

\section{Methodology}

\section{Sampling and data collection}

Sample hotels were identified from the highly respected directory of the Ministry of Tourism, Govt. of India and FHRAI that serves as a resource center for business information and maintains relevant databases of hospitality firms. To initiate the sample 15 five star hotels participated in the survey. They represented a mix of employees of the above-mentioned hotels and also the guests staying or have stayed with them on sustainability practices. A survey methodology was chosen because it was deemed to be the most efficient way of reaching a large number of respondents, whereas the data required facilitated the use of a mail and self-administered questionnaire with closeended questions. Of the total sample, usable questionnaires were returned by 740 respondents that included 375 Hotel Employees and 365 Hotel Guests.

\section{Results and Discussions}

Table 1

Represents the hotels that have been included in the survey which includes leading hotels approved by Ministry of Tourism, Government of India (Tourism, 2016)

\begin{tabular}{lll}
\hline S.No & City & Hotel Name \\
\hline 1 & New Delhi* & Jaypee Siddharth \\
2 & Delhi & J W Marriott \\
3 & New Delhi* & Park Plaza, Delhi \\
4 & Delhi & Piccadilly Hotels Pvt. Ltd. \\
5 Star Deluxe & \\
\hline
\end{tabular}




\begin{tabular}{lll}
\hline & City & Hotel Name \\
5 & Delhi & Hotel Welcome Sheraton \\
6 & Delhi & Hotel Amanbagh \\
7 & Delhi & Le Meridien New Delhi \\
8 & Delhi & Kempinski Ambience Hotel Delhi \\
9 & Delhi & ITC Maurya \\
10 & Delhi & The Oberoi, New Delhi (Closed for Renovation) \\
11 & Delhi & Hotel Imperial \\
12 & New Delhi* & The Taj Palace Hotel \\
13 & Delhi & The Park \\
14 & Delhi & Radisson Blu Hotel Dwarka \\
15 & Delhi & JW Marriott \\
16 & Delhi & The Lodhi \\
17 & Delhi & The Ashok \\
\hline
\end{tabular}

Table 2 represents the extent to which hotel applied sustainability management practices to provide more accurate data for decision making, respondents were asked to indicate the Importance and Usage of sustainability management practices. Further to structure the discussion of the findings we framed them according to their usage and importance in table 3. Three factors of sustainability management practices items have been identified based on exploratory principal components. Thus, the analysis provides a strong indication that traditional sustainability management practice is alive and well in the sample hotels. Therefore, $\mathrm{H} 1$ rejects as there is a significant difference in usage and importance of sustainability management practice in sample hotels. The use of star rated appliances has been ranked highly among practices for sustainability.

Table 2

Sustainability Practices

\begin{tabular}{llll}
\hline Sustainability Practices Adopted by Hotels & & SD & Sig. \\
Mean Square & & 3.496 & .008 \\
\hline Insulation of appliances and Fixtures to minimize heat gains/losses in your & 5.013 & & \\
hotel & 3.033 & 2.029 & .090 \\
Adequate Natural Lighting in day time & 4.564 & 3.667 & .006 \\
LED Lights & 7.206 & 5.848 & .000 \\
Reflective window Films & 5.280 & 3.045 & .017 \\
Alternate /Renewable energy e.g solar or biomass energy & 1.594 & 1.150 & .333 \\
Star rated appliances & 4.676 & 2.535 & .040 \\
Motion Sensor lighting/thermal devices & 4.225 & 3.007 & .018 \\
Periodical service of equipment & 5.485 & 4.233 & .002 \\
Thermostat range limited I occupied rooms & 5.049 & 3.135 & .015 \\
Adequate natural ventilation, and shading from trees and other vegetation to & & & \\
cool guest rooms, patios, etc. & 3.701 & 2.527 & .040 \\
Low-flow fittings. & 13.488 & 8.759 & .000 \\
Dual flush toilets. & 3.179 & 2.940 & .021 \\
Water recycling practices. & 1.873 & 1.442 & .220 \\
Re-use grey water to irrigate lawns etc & 13.594 & 6.916 & .000 \\
Sensor fittings in washrooms. & 12.650 & 6.186 & .000 \\
Rainwater harvesting for use in laundry etc. & 2.139 & 1.628 & .166 \\
Wastewater treatment plant. & 2.332 & 1.893 & .111 \\
Reduce, reuse and recycling of waste. & 9.291 & 7.837 & .000 \\
In-room linen recycling. & 8.018 & 5.747 & .000 \\
In-room amenities recycling & 7.550 & 7.228 & .000 \\
Facility for composting of waste. & 5.563 & 4.045 & .003 \\
Use of organic cleaning products & 9.774 & 3.767 & .005 \\
Donating left over food. & 6.213 & 5.159 & .000 \\
Purchase of hotel supplies from local vendors. & & & \\
\hline
\end{tabular}


CNG/Battery operated Vehicles

Provision of shuttle service for staff pick-up and drop.

Hotel's efforts for Workplace safety.

Hotel's effort for Work-life balance

Life Insurance benefits.

Provision of medical benefits

Provision of transportation facility.

Provision of Leave Travel Allowances

The hiring of a greater number of local staff over the outstation ones.

Hotel's efforts for improving employee satisfaction, morale and retention

Frequency of meetings held to discuss sustainability issues with the

employees.

Initial orientation program to educate new joinee towards sustainable

practices.

Your participation in Sustainability Practices.

Recognition is given for your distinguished achievements towards

sustainability

Hotel's initiative to employ people with disabilities.

Hotel's initiative for the upliftment of the surrounding areas and comes 8.178

Hotel's initiative to assist an NGO or underprivileged segment of society.

Hotel's initiative to purchase local products and supplies.

Hotel's initiative to support employment generating vocational training programs.

Hotel's initiative to supports traditional art \& craft-work.

Hotel's initiative to contribute donations to needy organizations.

Hotel's initiative to build ties with educational institutes and schools to

educate them about sustainability.

Hotel's initiative to build strong relations with its stakeholder's.

Leads to cost reduction.

Leads to increase in Occupancy of the hotel.

Leads to increase in Revenue.

Leads to higher Average Room Rates than your Competitors.

Leads to increase in profits.

Leads to improved company/brand image.

Involve huge Investments.

Results in employee's resistance to change.

Results in customer's resistance to adopting them.

Not feasible for the firm of this size.

Induces stronger compliance to environmental certification standards.

Induces stricter compliance with government environmental, legal and

economic legislation.

Triggers timely audits done to review energy and water usage and waste if any produced.

Inspires for the frequent introduction of new energy and labor saving

technologies.

Induces greater efforts for cost-savings.

Fosters more focus on improving the relationship with the stakeholders

including hotel staff, guests, suppliers, local communities, etc.

Inspires to adopt sustainability methods that improve revenue or cash flow.

Prompts more involvement in corporate social responsibility (CSR)

initiatives.

5.297

12.642

11.915

8.812

16.240

14.622

4.530

5.725

4.821

6.392

2.378

2.776

2.684

1.831

8.178

7.872

3.660

7.942

6.219

8.005

5.465

5.726

4.234

3.076

6.975

5.743

5.527

6.371

6.599

8.988

13.501

9.241

6.296

5.697

8.529

8.657

3.247

3.228

4.676

5.795
4.309

6.731

18.086

10.834

14.392

10.885

4.621

5.754

5.807

7.048

2.356

4.009

4.523

2.314

8.809

2.680

9.780

3.491

6.947

4.703

6.724

4.366

5.869

6.244

4.205

8.441

7.411

6.570

8.001

6.571

7.932

10.060

6.151

6.297

6.506

9.420

10.654

.000

3.934

4.132

.004

.003

6.795

7.472

.000

.000

Table 3 assesses the influence of sustainability practices by hotels on the basis of the demographic profile of competing hotels. The hotels taken in the survey for studying various sustainability practices have been studies on the basis of a number of rooms they have, the age of the hotel and also the type of hotel. The table shows that the 
type of hotel enterprise has a significant impact on the prevailing sustainability practices adopted among the hotels in the survey.

Table 3

Correlations

\begin{tabular}{lllll}
\hline Bi-Variate Correlation on Demographic Variables & $\begin{array}{l}\text { Number of } \\
\text { Rooms }\end{array}$ & Age of Property & $\begin{array}{l}\text { Type of } \\
\text { Enterprise/Hotel }\end{array}$ \\
\hline \multirow{3}{*}{ Number of Rooms } & Pearson Correlation & 1 & $-.263^{* *}$ & -.003 \\
& Sig. (2-tailed) & & .000 & .956 \\
\multirow{5}{*}{ Age of Property } & $\mathrm{N}$ & 375 & 374 & 375 \\
& Pearson Correlation & $-.263^{* *}$ & 1 & $.163^{* *}$ \\
\multirow{5}{*}{ Type of Enterprise/Hotel } & Sig. (2-tailed) & .000 & & .002 \\
& $\mathrm{~N}$ & 374 & 374 & 374 \\
& Pearson Correlation & -.003 & $.163^{* *}$ & 1 \\
& Sig. (2-tailed) & .956 & .002 & .004 \\
& $\mathrm{~N}$ & 375 & 374 & 375 \\
\hline
\end{tabular}

**. Correlation is significant at the 0.01 level (2-tailed).

\section{Conclusion}

The findings of this research paper suggest growing awareness, interest and seriousness towards employment of sustainability practices. There is a significant difference in usage and importance of sustainability management practices among competing Hotels. Though this development is significant, there is still work to be done in terms of consolidating the sustainability agenda.

\section{References}

American Management Association. (2007). Creating a sustainable future: A global study of current trends and possibilities 2007-2017. New York: American Management Association.

Basak, A., \& Khanna, K. (2017). A study on the selection criteria of different hotels of Delhi NCR in accordance to the $\mathrm{hr}$ policies and market trends. International Journal of Social Sciences and Humanities, 1(1), 27-38. https://doi.org/10.29332/ijssh.v1n1.13

Berezan, O., Millar, M., \& Raab, C. (2010). Hotel guests' perceptions of sustainable hotel practices in a Mexican destination.

Blackburn, W. R. (2012). The sustainability handbook: The complete management guide to achieving social, economic and environmental responsibility. Routledge.

Brundtland, G., Khalid, M., Agnelli, S., Al-Athel, S., Chidzero, B., Fadika, L., ... \& Singh, M. (1987). Our common future ('brundtland report $\mid$ ').

Dauvergne, M., \& Li, G. (2006). Homicide in Canada, 2005. Canadian Centre for Justice Statistics.

Elkington, J. (1994). Towards the sustainable corporation: Win-win-win business strategies for sustainable development. California management review, 36(2), 90-100. https://doi.org/10.2307\%2F41165746

Elkington, J. (1998). Partnerships from cannibals with forks: The triple bottom line of 21st-century business. Environmental quality management, 8(1), 37-51. https://doi.org/10.1002/tqem.3310080106

Esty, D., Esty, D. C., \& Simmons, P. J. (2011). The green to gold business playbook: How to implement sustainability practices for bottom-line results in every business function. John Wiley \& Sons.

Gamez, MR, Perez, AV, Falcones, VAM, \& Bazurto, JJB (2019). The geoportal as strategy for sustainable development. International Journal of Physical Sciences and Engineering, 3(1), 1021. https://doi.org/10.29332/ijpse.v3n1.239

Gorda, A. O. S., Romayanti, K. N., \& Anggreswari, N. P. Y. (2018). Social capital, spiritual capital, human capital, and financial capital in the management of child welfare institutions. International Journal of Social Sciences and Humanities, 2(3), 12-20. https://doi.org/10.29332/ijssh.v2n3.183

Grant, R. (2010). Comporary Strategy Analysis 7th Edition. 
Gupta, A. (2012). Sustainable competitive advantage in service operations: An empirical examination. Journal of Applied Business Research, 28(4), 735.

Johnston, C. P., Qiu, H., Ticehurst, J. R., Dickson, C., Rosenbaum, P., Lawson, P., ... \& Green, K. Y. (2007). Outbreak management and implications of a nosocomial norovirus outbreak. Clinical Infectious Diseases, 45(5), 534-540.

Kotler, P., \& Lee, N. (2008). Corporate social responsibility: Doing the most good for your company and your cause. John Wiley \& Sons.

Mihalič, T., Žabkar, V., \& Cvelbar, L. K. (2012). A hotel sustainability business model: evidence from Slovenia. Journal of Sustainable Tourism, 20(5), 701-719. https://doi.org/10.1080/09669582.2011.632092

Munier, N. (2005). Introduction to sustainability. The Netherlands: Springer.

Pérez, A. V., Gámez, M. R., Briones, V. F. V., Viteri, C. G. V., \& Molina, L. A. V. (2018). Sustainable development seen from environmental training in university linkage. International Journal of Life Sciences, 2(1), 12-20. https://doi.org/10.29332/ijls.v2n1.75

Perez, A. V., Gamez, M. R., Sera, A. S., \& Santos, R. D. (2018). Sustainable energy development: its postulates and principles in the community. International Journal of Social Sciences and Humanities, 2(2), 214-225. https://doi.org/10.29332/ijssh.v2n2.167

Porter, T., \& Derry, R. (2012). Sustainability and business in a complex world. Business and Society Review, 117(1), 33-53. https://doi.org/10.1111/j.1467-8594.2012.00398.x

Prairie, J. C., Sutherland, K. R., Nickols, K. J., \& Kaltenberg, A. M. (2012). Biophysical interactions in the plankton: A cross-scale review. Limnology and Oceanography: Fluids and Environments, 2(1), 121-145.

Rathore, J., Gawankar, D., \& Mills, J. E. (2009). Exploring sustainability practices in the hotel industry. University of new haven Undergraduate Research Fellowship, 1-5.

Revilla, G., Dodd, T. H., \& Hoover, L. C. (2001). Environmental tactics used by hotel companies in Mexico. International Journal of Hospitality \& Tourism Administration, 1(3-4), 111-127. https://doi.org/10.1300/J149v01n03_07

Spilanis, I., \& Vayanni, H. (2004). 13 Sustainable Tourism: Utopia or Necessity? The Role of New Forms of Tourism in the Aegean Islands. Coastal mass tourism: Diversification and sustainable development in Southern Europe.

Tryggestad, K., Georg, S., \& Hernes, T. (2010). Constructing buildings and design ambitions. Construction management and economics, 28(6), 695-705. https://doi.org/10.1080/01446191003755441

Visser, W. (2011). The age of responsibility: CSR 2.0 and the new DNA of business. John Wiley \& Sons.

Werbach, A. (2009). When sustainability means more than green. Mckinsey quarterly, 4(2009), 74-9.

Wirtenberg, J. (2012). Triple-Bottom-Line. Leadership Excellence, 29(6), 8. 